\title{
Variations of Glaciar Coronas, Pyrenees, Spain, during the 20th century
}

\author{
Javier CHUEGA, ${ }^{1}$ Asunción JULiÁn, ${ }^{2}$ Ignagio LÓPEZ ${ }^{3}$ \\ ${ }^{1}$ Departamento de Geografia, Facultad de Ciencias Humanas y de la Educación, Universidad de Zaragoza, ES-22002 Huesca, Spain \\ E-mail: jchueca@posta.unizar.es \\ ${ }^{2}$ Departamento de Geografia, Universidad de Zaragoza, ES-50009 Zaragoza, Spain \\ ${ }^{3}$ Instituto Pirenaico de Ecologia, Consejo Superior deInvestigaciones Cientificas, Avda. Montañana 1005, Apdo. 202, ES-50.059 Zaragoza, Spain
}

\begin{abstract}
Glaciar Coronas is one of the small cirque glaciers located in the Maladeta Range, central Spanish Pyrenees. The ice extends from 3220 to $3065 \mathrm{~m}$ a.s.l. Using early and modern photographs and aerial photographs, we study the evolution of the glacier during the 20th century, with particular focus on evaluating the variations in area, ice thickness and the withdrawal of the ice front. This information is compared with some basic climatic data (quarterly and annual evolution of temperatures and precipitation) recorded in the nearby Seira observatory. The results show that ice wastage, clearly associated with the main regional climatic evolution, has been dominant during the 20th century at Glaciar Coronas, but the rate has varied and has not been continuous. Three periods have been detected: (1) 1920s-early 1960s: ice depletion period; (2) early 1960smid-1980s: stabilization of the deglaciation process; (3) mid-1980s-1998: marked ice depletion period. The study shows a decrease in area of Glaciar Coronas from 19 ha in 1928 to 2.4 ha in 1998. The decrease in length from 1928 to 1998 has been $325 \mathrm{~m}$.
\end{abstract}

\section{INTRODUCTION}

The objective of this work is to reconstruct the glacier retreat observed in Glaciar Coronas, Spain, during the 20 th century. This small glacier is located at $42^{\circ} 38^{\prime} 00^{\prime \prime} \mathrm{N}$, $0^{\circ} 39^{\prime} 20^{\prime \prime} \mathrm{E}$ in the Maladeta Range, in a southwest-facing cirque eroded into the granodiorites of Pico de Aneto (3404 $\mathrm{m}$ a.s.l.), the highest peak of the Pyrenees (Fig. 1). The glacierization of the Pyrenees is of particular interest in the context of climatic change in European mountain regions, due to its situation in middle, temperate latitudes. In the Pyrenees, as in most other parts of the Northern Hemisphere, glaciers began to recede from their Little Ice Age (LIA) maximum positions around the mid-19th century (Chueca and others, 1998). The climatic trends registered in the area during the 20th century have enhanced this process, and the shrinkage of Glaciar Coronas is an excellent example.

The Maladeta Range has the best-preserved and largest ice masses in the whole Pyrenean Range. Almost all of them are small north-northeast-facing cirque glaciers, covering a total area of around $200 \mathrm{ha}$, the three most extensive being Glaciares Aneto (100 ha), Maladeta del Este (52 ha) and Tempestades (28 ha) (Julián and others, 2001). The ice masses are situated at $2800-3300 \mathrm{~m}$ a.s.l. on northern slopes, with a few in south-facing cirques $3000-3200 \mathrm{~m}$ a.s.l. Ice depths vary across each cirque, the maximum thickness, measured by geophysical methods, being $40-50 \mathrm{~m}$ in Glaciares Aneto and Maladeta (Martínez and others, 1997). The equilibrium-line altitude (ELA) in the zone is about 3000-3100 m a.s.l. (Chueca and Julián, 1994). Glaciar Coronas is the most extensive ice mass on the southern slopes of the Maladeta Range (Fig. 2). It has recently separated into several bodies, of which the largest is a glacieret with a surface of 2.4 ha located at 3065-3220 $\mathrm{m}$ a.s.l. Today, the sum of its five largest fragments slightly surpasses 3 ha; during the LIA maximum the ice extent was 37 ha. These data illustrate the ice depletion of the area during the last century.

Glaciar Coronas has traditionally been used as a direct route to the summit of the Pyrenees, the Pico de Aneto. Consequently, there is a relatively abundant graphical documentation (photographs, aerial photographs, cartography) of the state and recent evolution of the glacier. Once compiled and analyzed, the record has served to accomplish our main objective: to reconstruct and map the ice mass during five stages (1928; 1957; 1980-81; 1990; 1998), to which we have added an initial phase, the LIA maximum, dated in the moraine deposits of the area around 1820-30 (Chueca and Julián, 1996). In section 3 of our study, this information, of a qualitative rather than quantitative nature, is compared with some basic climatic data (temperature and precipitation) recorded at the nearby Seira weather station since 1921. This comparison allows us to detect the influence of the climate on the dynamics of Glaciar Coronas, explaining the phases of glacier recession, stabilization and accelerated downwasting.

\section{DOGUMENTATION OF IGE EXTENT: GLAGIAR GORONAS FLUGTUATIONS}

The evolution of glaciers since the LIA in the Pyrenees has been studied in more detail in the French (northern) sector of the range than in the Spanish (southern) sector (Degrange, 1882; Bonaparte, 1890, 1891; Schrader, 1894; Russell, 1908; Gaurier, 1912, 1921, 1934; Galibert, 1956; Barrère, 1963; Camena, 1969; Serrat, 1980; Martínez de Pisón and 


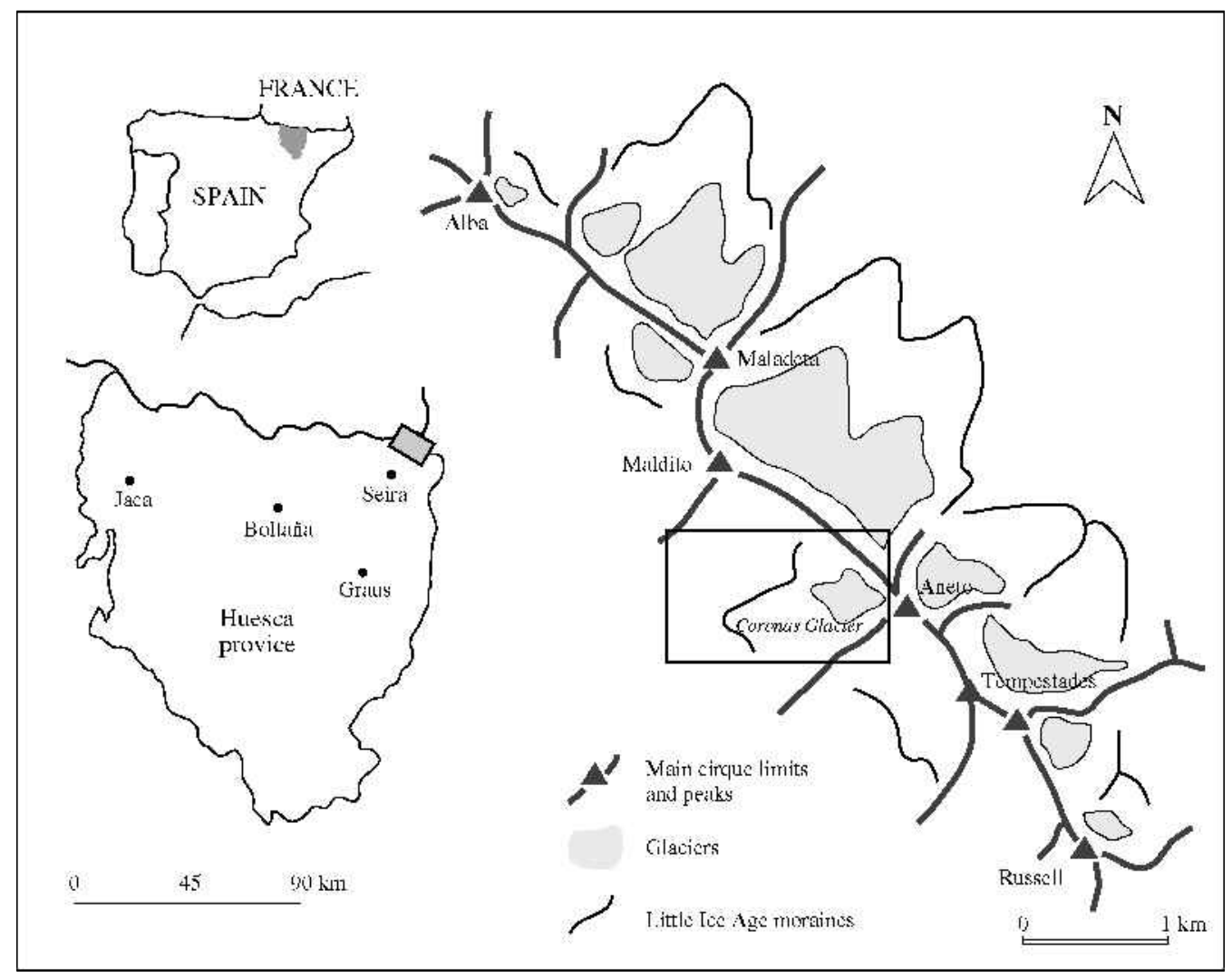

Fig. 1. Location of Glaciar Coronas in the study area, Maladeta Range, central Spanish Pyrenees.

Arenillas, 1988; Gellatly and others, 1995; Chueca and others, 1998), and these glaciers have attracted relatively little attention compared with those in the European Alps. In the Maladeta Range, this evolution has been outlined in several works (Copons and Bordonau, 1994; Lampre, 1994, 1996; Chueca and Julián, 1996, 1999).

Two main sources of documentary evidence were used to map the glacier extent at each stage: (1) Aerial photographs are generally highly reliable, especially the 1957 aerial survey. The 1981 survey offers greater detail, but the snow cover is extensive, so it has only been used to support the interpret-

Table 1. Glaciar Coronas changes, 1820-30, 1928, 1957, 1980-81, 1990 and 1998

Stage

$\begin{array}{lllll}1820-30 & 1928 \quad 1957 \quad 1980-81 \quad 1990 \quad 1998\end{array}$

\section{Surface area}

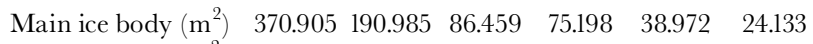

Ice fragment $1\left(\mathrm{~m}^{2}\right)$

$\begin{array}{lrr}\text { Ice fragment } 2\left(\mathrm{~m}^{2}\right) & 2.695 & 2.629\end{array}$

Ice fragment $3\left(\mathrm{~m}^{2}\right) \quad 1.715 \quad 1.325$

Ice fragment $4\left(\mathrm{~m}^{2}\right) \quad 1.278$

Ice thickness

$\begin{array}{lllllll}\text { Max. altitude (m a.s.l.) } & 3.250 & 3.250 & 3.250 & 3.250 & 3.250 & 3.220\end{array}$

$\begin{array}{lllllll}\text { Min. altitude (m a.s.l.) } & 2.780 & 2.910 & 3.020 & 3.020 & 3.060 & 3.065\end{array}$

$\begin{array}{lllllll}\text { Max length }(\mathrm{m}) & 1.050 & 600 & 350 & 350 & 325 & 275\end{array}$

$\begin{array}{lllllll}\text { ELA (m a.s.l.) } & 2.994 & 3.065 & 3.122 & 3.123 & 3.132 & 3.145\end{array}$

Status Glacier Glacier Glacier Glacier Glacier Glacieret

Note: Ice-thickness information $(<$, ablation; $=$, stabilization $)$ is a qualitative estimation of the evolution of this parameter between stages. ations of the second type of documents. (2) Terrestrial photographs are very useful if taken from similar places, and if the images are extensive (i.e. they include the whole or a major part of the glacier). Correct dating, especially of the oldest documents, is a serious problem, so the only photographs used in our study are those for which a trustworthy chronology can be established: 1928, 1980, 1990 and 1998.

This evidence has been used to construct the cartography of the Glaciar Coronas evolution presented in Figure 3 and Table 1. The area-extent data correspond with the values of planimetric surface area; therefore, the actual surface area is likely to be slightly larger than cited here. A simple measure of volumetric change is also undertaken (by visual estimation of the ice thickness at several control points located on the Coronas glacial cirque walls). In this way, we have captured the apparent tendency of the glacier mass to increase, stabilize or diminish.

(1) 1820-30. As a starting point of reference, we have used the maximum extent reached by Glaciar Coronas during the LIA, suggested by the prominent arcuate moraine shown in Figure 4, dated in the moraine deposits of the Maladeta Range to around 1820-30 (Chueca and Julián, 1996). The ice extent at that time was $37 \mathrm{ha}$, and the glacier length was slightly over $1 \mathrm{~km}$. Maximum and minimum altitudinal levels of the ice mass were 3250 and $2780 \mathrm{~m}$ a.s.l. The ELA (estimated by the classic Kurowski method; Osmaston, 1975) was at $2994 \mathrm{~m}$ a.s.l.

(2) 1928. A photograph by an unknown author, released as a postcard in 1928, shows the glacier situation at that time (Fig. 5). Since the LIA maximum, considerable change has taken place: the glacier ice front is now clearly withdrawn from the moraine, and the reduction in surface 


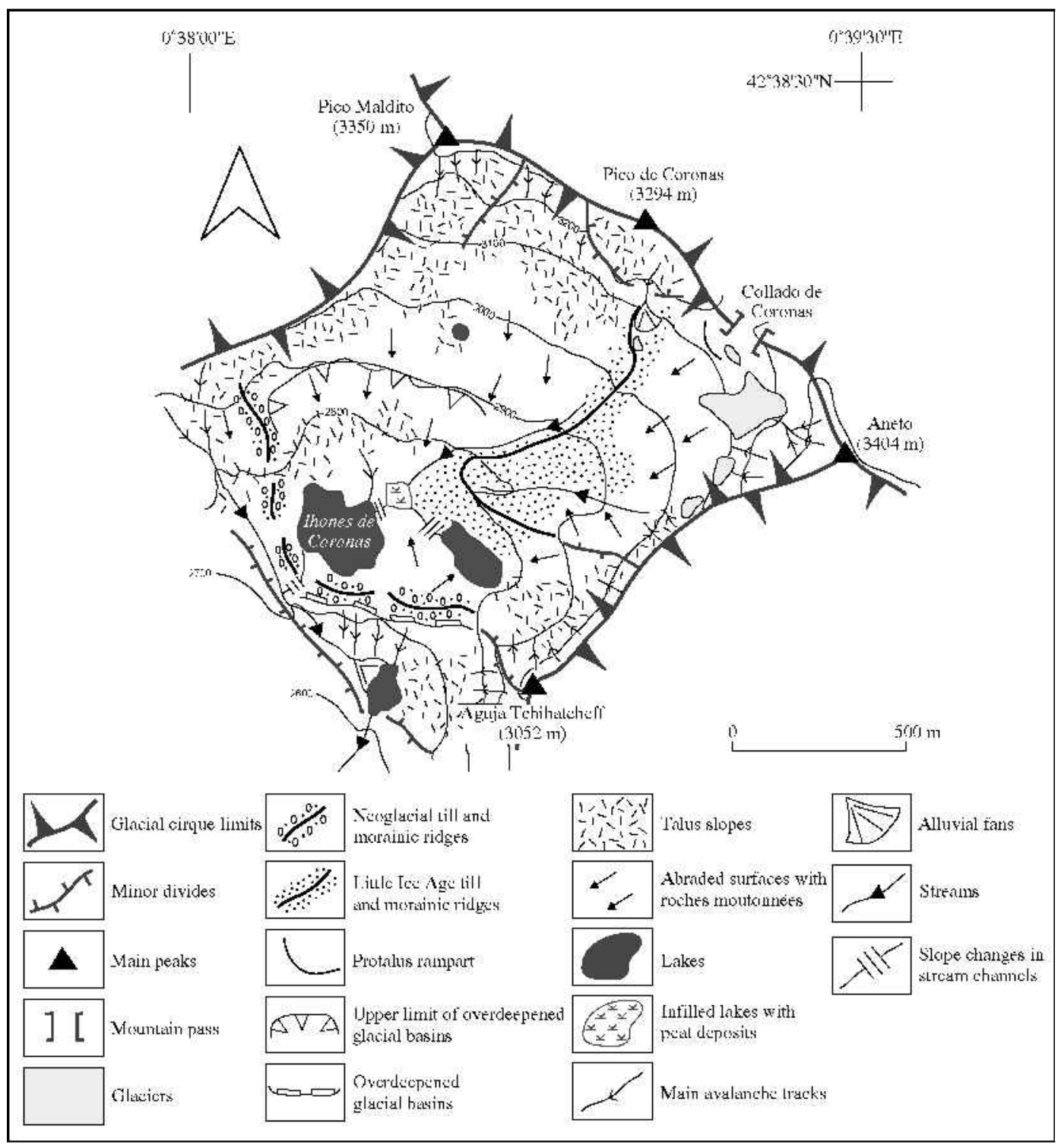

Fig. 2. Geomorphological map of Coronas cirque.

area is considerable. The glacier extent is approximately $19 \mathrm{ha}$, the length $600 \mathrm{~m}$, and the maximum and minimum altitudinal levels 3250 and $2910 \mathrm{~m}$ a.s.l.; the estimated ELA for this stage was located at $3065 \mathrm{~m}$ a.s.l.

(3) 1957. The first vertical aerial photograph of the area was taken in 1957 (American flight; August 1957; photo No. 59539), providing a well-defined view of Glaciar Coronas. The recession process is extremely noticeable: between 1928 and 1957 the glacier front had retreated about $250 \mathrm{~m}$, having an extent of just 8.6 ha in its main fragment. Maximum and minimum altitudinal levels are 3250 and $3020 \mathrm{~m}$ a.s.l. The ELA is placed at $3122 \mathrm{~m}$ a.s.l.

(4) 1980-81. For this stage we refer to the information provided by the 1981 aerial survey (south Pyrenees flight; September 1981; photo No. 8468), and a contemporary photographic document (Fig. 6) published by Martínez de Pisón and Arenillas (1988). For the most part, there is remarkably little difference in estimated extent and profile since 1957. The ice-mass extent of the glacier is now $7.5 \mathrm{ha}$; the maximum and minimum altitudinal levels, length, and ELA position are almost the same as the 1957 values.
(5) 1990. Ten years after the previous stage, thinning and lateral shrinkage is again observed. Several photographs show this evolution (Fig. 7), which is confirmed by the fragmentation of Glaciar Coronas into several smaller bodies. The extent of the greater fragment in this phase was 3.8 ha, with a length of $325 \mathrm{~m}$. Maximum and minimum altitudinal levels of the ice mass were placed at 3250 and $3060 \mathrm{ma}$ a.s. ; the estimated ELA was at $3132 \mathrm{~m}$ a.s.l.

(6) 1998. The last of the stages analyzed shows the situation of Glaciar Coronas at the present time. Photographs taken during the 1998 glaciological survey coordinated by the Spanish Consejo de Protección de los Glaciares (Chueca and others, 2000) show a noticeable degradation in the ice mass. The glacier is now a glacieret, thinned and apparently (no data on velocity are available) lacking any dynamism (Fig. 8). The extent has been reduced, in its main fragment, to 2.4 ha, with a length of $275 \mathrm{~m}$. Maximum and minimum altitudinal levels are located at 3220 and $3065 \mathrm{~m}$ a.s.l.; the estimated ELA is positioned at $3145 \mathrm{~m}$ a.s.l. (Table 1 ). 


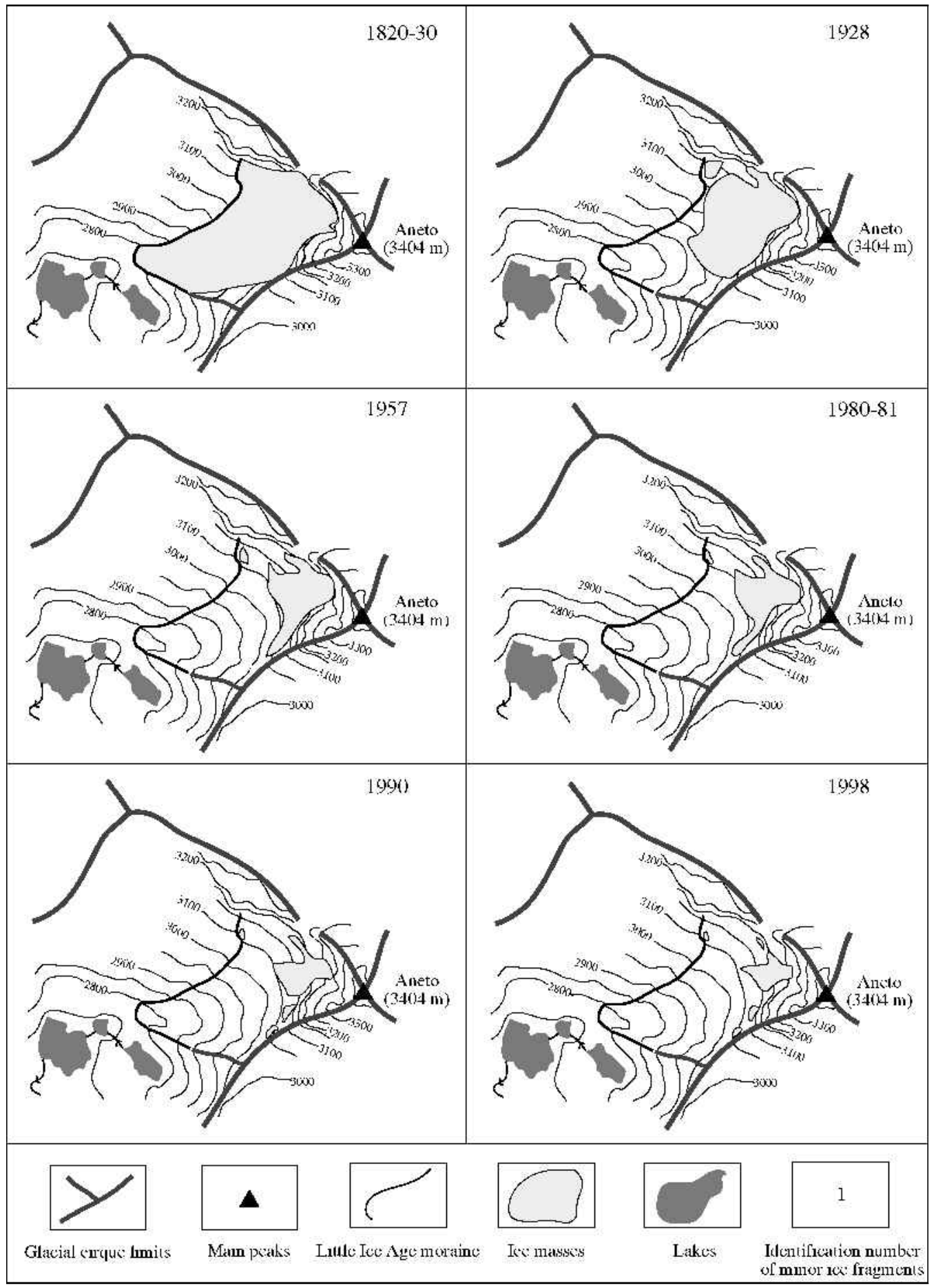

Fig. 3. Glaciar Coronas ice extent in 1820-30, 1928, 1957, 1980-81, 1990 and 1998.

\section{GLIMATIG-DATA VARIATION}

\subsection{Collection of climate data}

The Seira weather observatory has relatively long precipitation and temperature records (temperatures: 1941-94; precipitation: 1919-94). It is located at $815 \mathrm{~m}$ a.s.l., around $20 \mathrm{~km}$ southwest of the Maladeta Range (Fig. 1). The monthly temperature and precipitation data were treated to fill incomplete months in the period 1938-39 and to extend the series until 1998 using linear regressions with data from the nearby Graus observatory (statistically significant for both temperature and precipitation values; $r^{2}>$ 0.7 ; significance level $\alpha=0.01$ ). Selected values (with dataseries average values for temperature and precipitation, and a 5 year moving average for temperature) are presented in Figures 9 and 10: data were grouped in quarterly values (first-quarter temperatures (January-March), third-quarter temperatures (July-September); fourth-quarter precipitation (October-December), first-quarter precipitation and second-quarter precipitation (April-June)) and annual values. This selection is useful as it reflects those periods of the year thought most important for understanding summer and winter glacier balances.

\subsection{Glaciar Coronas variations as a function of climate}

Detailed analysis of the relationships between glacier fluctuations and climatic changes is hampered by the absence 


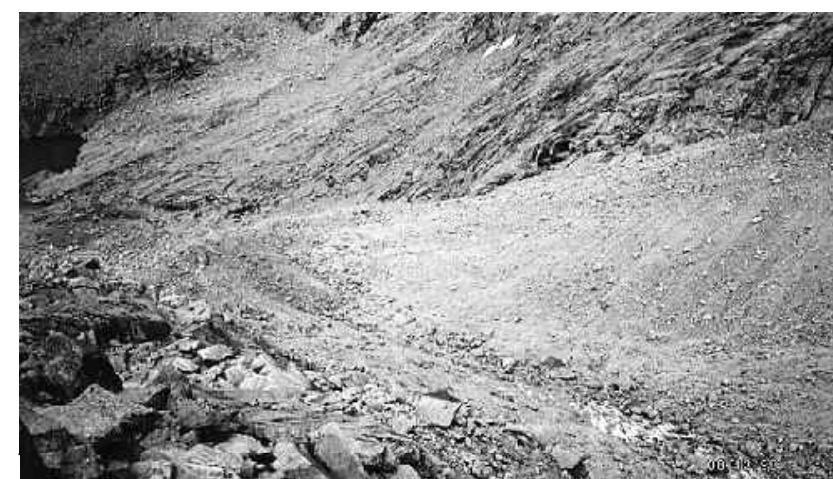

Fig. 4. Photograph showing the Glaciar Coronas LIA arcuate moraine terminal area (photograph by E. Blanchard).

of mass-balance studies on Glaciar Coronas. Besides, there is an obvious mismatch between our two datasets, with continuous temperature and precipitation records from the 1920 s, but intermittent records of glacier extent. Overall, as we have pointed out, ice depletion was clearly dominant during the 20th century at Glaciar Coronas, but the rate has varied and has not been continuous. The primary factors controlling glacier mass balance are undoubtedly temperature and precipitation, and the fluctuations of Glaciar Coronas during this period show good agreement with the variations of these two climatic variables, apparently much clearer in the case of temperature.

(1) 1920 s-early 1960s: ice depletion period (glacier surface 1928-57 receded from 19 to 8.6 ha; front of the glacier withdrew $250 \mathrm{~m}$ ). Temperatures were always above the data-series average value (annual, summer and winter quarters), with maxima in the second half of the 1940s, favouring melting processes during winter and long ablation seasons. The influence of precipitation on the glacier mass balance in this phase is not so obvious, since in the four analyzed variables (first, second and fourth quarters and annual total) fluctuations are both above and below average throughout the period. But even though no clear trend is detected, examination shows that there are more years with below-average values than humid years, favouring the incidence of ablation processes in the glacier.

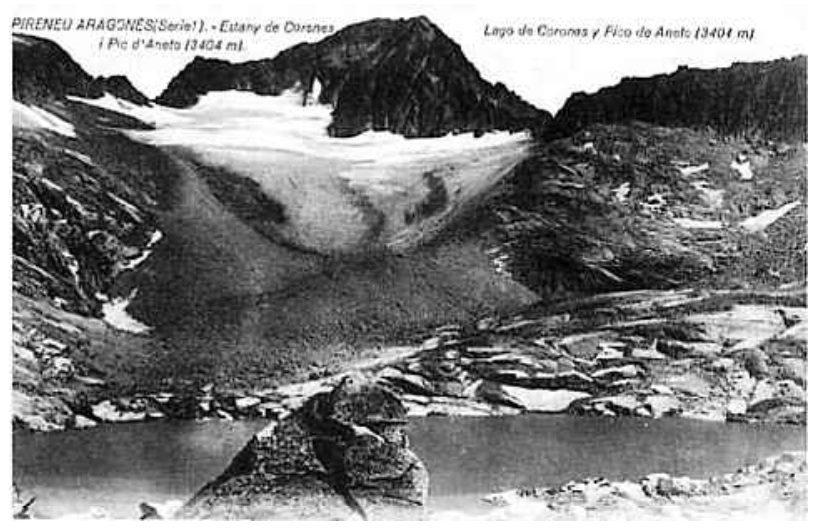

Fig. 5. View of Glaciar Coronas and its LIA moraine taken from Ibones de Coronas in 1928. The highest elevation in the centre of the postcard is Pico de Aneto; Collado de Coronas is also visible in the left distance (photographer unknown).

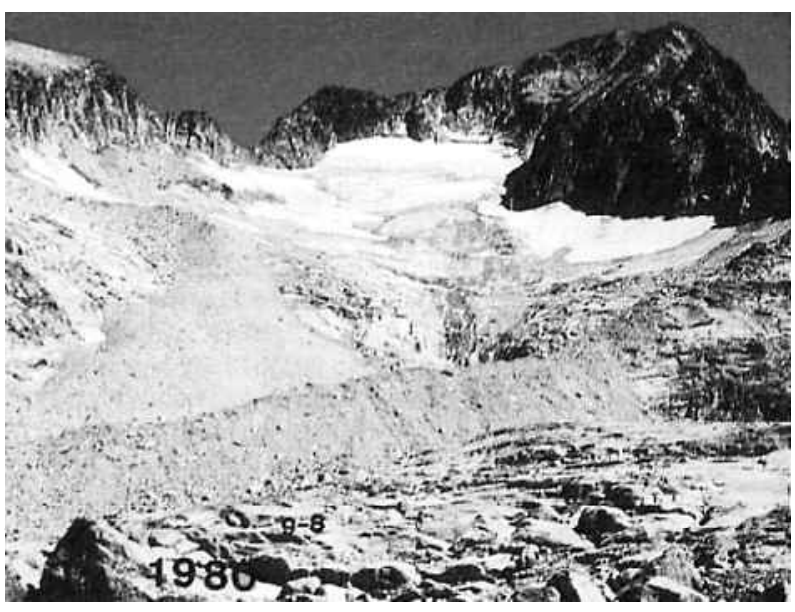

Fig. 6. View of Glaciar Coronas and its LIA moraine taken from Ibones de Coronas in 1980 (photograph by E. Martinez de Pisón and M. Arenillas).

(2) Early 1960s-mid-1980s: stabilization of the deglaciation process (glacier surface 1957-81 slightly receded from 8.6 to $7.5 \mathrm{ha}$; withdrawal of the front of the glacier not evident). In this phase, both climatic factors seem to contribute to the preservation of the ice mass. Temperatures (in the three cases) show a marked reduction, which culminates in the first half of the 1970s, and almost throughout this period the precipitation (in the four cases) is around or above average values.

(3) Mid-1980s-1998: marked ice depletion period (glacier surface 1981-98 receded from 7.5 to 2.4 ha; front of the glacier withdrew about $75 \mathrm{~m}$ ). The two studied climatic variables continue to have a strong influence on the glacier evolution. In the case of temperatures, the three considered values are scarce but constantly above the data-series average (with summer temperatures peaking in the early 1990s, and winter temperatures in the second half of the 1990s). In addition, precipitation was almost always well below average in the three studied quarters (particularly in the winter months) and in the annual total accumulation.

In general, periods during which the climate favoured positive mass balances saw only slight stabilization in ice volume and surface area, and this was insufficient to interrupt the general recessional trend. The sensitivity to

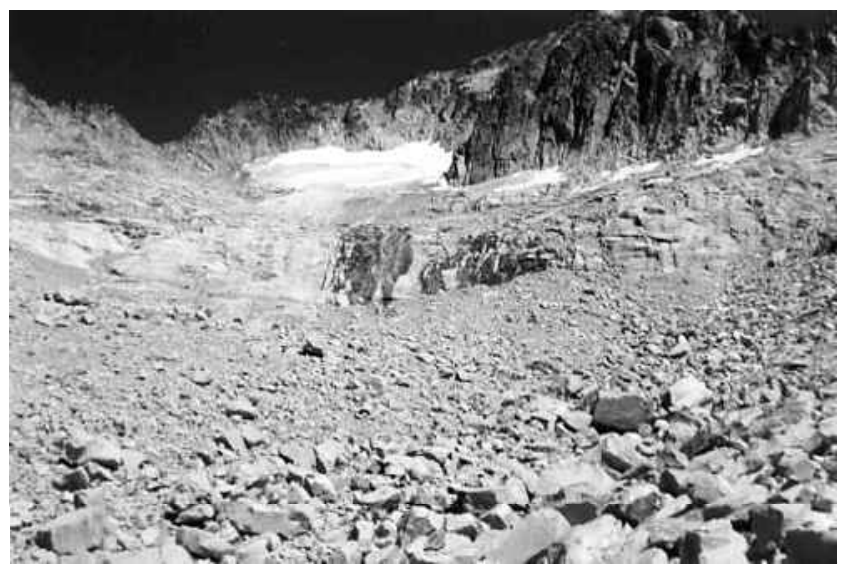

Fig. 7. View of Glaciar Coronas taken in the vicinity of its LIA moraine in 1990 (photograph by I. López). 


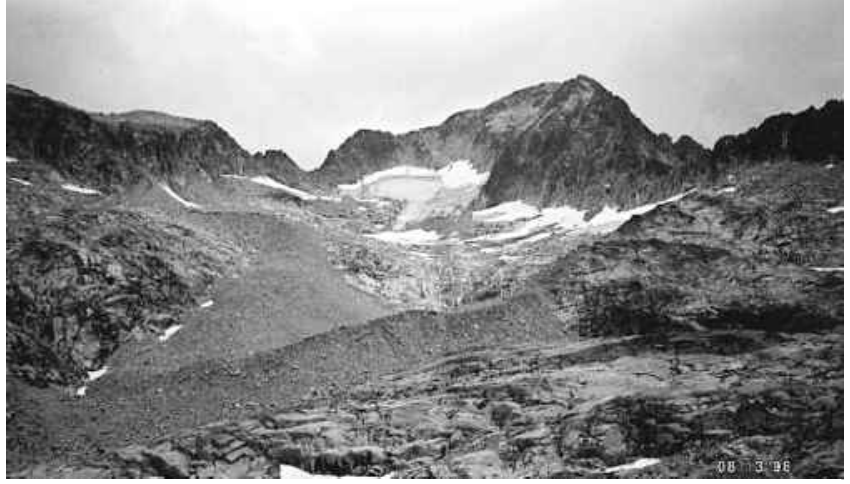

Fig. 8. View of Glaciar Coronas and its LIA moraine taken from Ibones de Coronas in 1998. Since 1928 the withdrawal of the glacier front, its separation into several bodies and the loss in ice thickness is evident (photograph by E. Blanchard).

regional climate of Glaciar Coronas is reflected in the rapid response and adjustment of the glacier fluctuations (evidenced in the ice-front recession or in volume losses) to mass-balance changes. The fact that the glacier lacks a debris cover on its surface, which would reduce ablation, contributes to the process. A minimal time lag (of very few years) seems to exist between temperature and precipitation evolution and responses at the ice front, but lack of continuous glacier-extent data makes this impossible to confirm.

Glaciar Coronas shows the same tendency as other alpine Mediterranean glaciers, which experienced a constant rise in ELAs during the 20th century (particularly in recent decades), as well as an almost continuous sequence of negative mass balances. This has been true of the small glaciers of the Southern Maritime Alps (Gellatly and others, 1994b; Pappalardo, 1999); Ghiacciaio del Calderone, central Apennines, Italy (Gellatly and others, 1994a; D’Orefice and others, 2000); Glaciar Corral del Veleta, Sierra Nevada, southern Spain (Messerli, 1980; Gómez Ortiz and Salvador, 1997); and the other glaciated areas in the southern Pyrenees (Chueca and others, 2000; Julián and others, 2001). In the northern, more humid Pyrenees, the recession in surface area has also been significant, but less marked. The study by Gellatly and others (1995) of Glacier du Taillon, French Pyrenees, showed a decrease in its area from 31 ha in 1924 to 20 ha in 1994 (35.5\%), while Glaciar

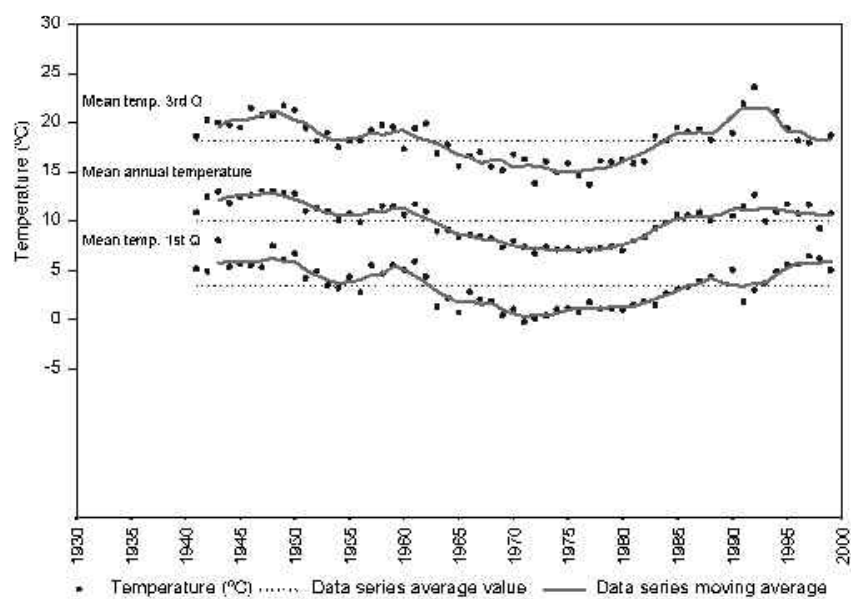

Fig. 9. Temperature record from Seira weather observatory.

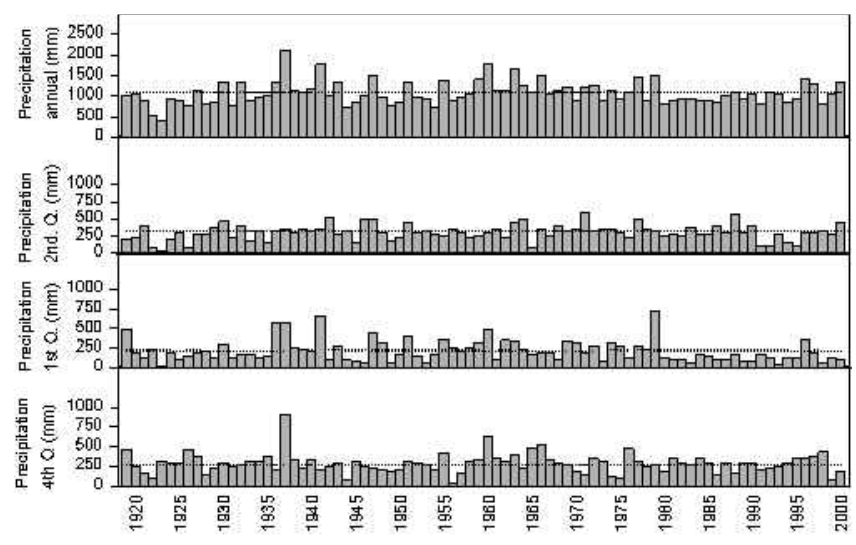

$\square$ Precipitation (mm) …… Data series average value

Fig. 10. Precipitation record from Seira weather observatory.

Coronas decreased from 19 ha in 1928 to 2.4 ha in 1998 $(87.4 \%)$; and a recession in its length by about $150 \mathrm{~m}$ from 1928 to 1994, whereas Glaciar Coronas decreased by $325 \mathrm{~m}$ from 1928 to 1998.

The timing of this deglaciation process is not the same in all alpine Mediterranean areas, due to the importance of local factors such as topography, shading, presence of debris-cover accumulations or particular topoclimatic conditions; but the general trend towards reduction of the surface area and thickness, or even glacier extinction, is consistent throughout the region.

\section{GONCLUSIONS}

Glacier fluctuations have frequently been used as indicators of climatic change, with changes marked by movement of the glacier front positions or by losses in ice mass. Glaciar Coronas is a good example of the relationship between climate and glacier fluctuations in a mid-latitude Mediterranean alpine context. Recession has dominated the 20thcentury history of Glaciar Coronas, with rapid ice depletion occurring since the mid-1980s. Wastage has been interrupted by stationary periods, but the separation of the glacier into several parts during the last two decades indicates the possibility of very rapid depletion of the small ice fragments of this ice mass. Future minor changes in temperatures or precipitation in this Pyrenean area should cause a quick response in the evolution of these fragile ice remnants.

\section{ACKNOWLEDGEMENTS}

This study was supported by the Gobierno de Aragón (project H-9007 Estudio de la dinámica de los glaciares del Pirineo aragonés) and the ECLIPSE program (Environnement et climat du passé: histoire et évolution). N. F. Glasser, Scientific Editor for the paper, and I. Owens provided many useful comments that improved the manuscript.

\section{REFERENGES}

Barrère, P. 1963. La période glaciaire dans l'ouest des Pyrénées centrales Franco-espagnoles. Revue Géographique des Pyrénées et du Sud-Ouest, 24(2), $116-134$.

Bonaparte, R. 1890. Les variations périodiques des glaciers français II. Ann. Club Alpin Français 17, 423-427. 
Bonaparte, R. 1891. Les variations périodiques des glaciers français III. Ann. Club Alpin Français 18, 482-519.

Camena, P. 1969. Les Pyrénées. Amsterdam, Meridian.

Chueca, J. and A. Julián. 1994. El medio natural de la Alta Ribagorza: Macizo de la Maladeta. Madrid, Colectivo Naturalia.

Chueca, J. and A. Julián. 1996. Datación de depósitos morrénicos de la Pequeña Edad del Hielo: macizo de la Maladeta. In Pérez Alberti, A., P. Martini, W. Chesworth and A. Martinez Cortizas, eds. Dinámica y evolución de medios Cuaternarios. Santiago de Compostela, Xunta de Galicia, $171-182$.

Chueca, J. and A. Julián. 1999. Reconstrucción de valores térmicos a partir del análisis espacial de morrenas glaciares en el Macizo de la Maladeta (Pirineo central español): siglos XVII-XX. In Raso, J. M. and J. Martin-Vide, eds. La climatologia española en los albores del siglo XXI. Barcelona, Publicaciones de la Asociación Española de Climatologia, 139-148.

Chueca, J., J. L. Peña, F. Lampre, J. M. García-Ruiz and C. Martí Bono. 1998. Los glaciares del Pirineo aragonés: estudio de su evolución y extensión actual. Zaragoza, Universidad de Zaragoza.

Chueca, J., J. L. Peña, A. Julián and E. Blanchard. 2000. Dinámica de los glaciares del Pirineo aragonés: resultados de la campaña glaciológica del año 1998. Boletin Glaciológico Aragonés, 1, 13-41.

Copons, R. andJ. Bordonau. 1994. La Pequeña Edad del Hielo en el Macizo de la Maladeta (Alta cuenca del Ésera, Pirineos centrales). In Martí Bono, C. and J. M. García-Ruiz, eds. El glaciarismo surpirenaico: nuevas aportaciones. Logroño, Geoforma Ediciones, 111-124.

Degrange, A. 1882. Note sur le retrait des glaciers Pyrénéens. Ann. Club Alpin Français 9, 560-579.

D'Orefice, M., M. Pecci, C. Smiraglia and R. Ventura. 2000. Retreat of Mediterranean glaciers since the Little Ice Age: case study of Ghiacciaio del Calderone, central Apennines, Italy. Arct. Antarct. Alp. Res., 32(2), 197-201.

Galibert, G. 1956. Le relief de haute montagne dans les massifs de Luchon et des Monts Maudits. Revue Géographique des Pyrénées et du Sud-Ouest, 17(2), 41-73.

Gaurier, L. 1912. Observations glacieres dans les Pyrénées. Rapports annuels de 1905 à 1911, détaillant par massifs. Études Glaciologiques SavoiesPyrénées 9, 560-579.

Gaurier, L. 1921. Études glacieres dans les Pyrénées françaises et espagnoles de 1900 à 1909. Pau, Garet-Haristoy.

Gaurier, L. 1934. Études glaciologiques 1920-1930. Études Glaciol. 4, 93-120.

Gellatly, A. F., J. M. Grove, R. Latham and R. J. Parkinson. 1994a. Observations of the glaciers in the Southern Maritime Alps (Italy). Revue de Géomorphologie Dynamique, 43(3), 93-107.
Gellatly, A. F., C. Smiraglia, J. M. Grove and R. Latham. 1994b. Recent variations of Ghiacciaio del Calderone, Abruzzi, Italy. 7. Glaciol., 40(136), 486-490.

Gellatly, A. F., J. M. Grove, A. Bücher, R. Latham and W. B. Whalley. 1995. Recent historical fluctuations of the Glacier du Taillon, Pyrénées. Phys. Geogr., 15(5), 399-413.

Gómez Ortiz, A. and F. Salvador. 1997. El glaciarismo de Sierra Nevada, el más meridional de Europa. In Gómez Ortiz, A. and A. Pérez Alberti, eds. Las huellas glaciares de las montañas españolas. Santiago de Compostela, Universidade de Santiago de Compostela, 385-430.

Julián, A., J. Chueca, J. L. Peña, I. López and A. Lapeña. 2001. Dinámica de los glaciares del Pirineo aragonés: resultados de la campaña glaciológica del año 1999. Boletin Glaciológico Aragonés 2, 13-36.

Lampre, F. 1994. La línea de equilibrio glacial y los suelos helados en el macizo de la Maladeta (Pirineo aragonés): evolución desde la Pequeña Edad del Hielo y situación actual. In Martí Bono, C. and J. M. GarcíaRuiz, eds. El glaciarismo surpirenaico: nuevas aportaciones. Logrofio, Geoforina Ediciones, 125-142.

Lampre, F. 1996. Evolución glacial de Ballibierna (Macizo de la Maladeta, Pirineo aragonés). In Pérez Alberti, A., P. Martini, W. Chesworth and A. Martinez Cortizas, eds. Dinámica y evolución de medios Cuaternarios. Santiago de Compostela, Xunta de Galicia, 143-155.

Martínez, R., F. García, Y. Macheret, J. Navarro and L. Bisbal. 1997. El sustrato subglaciar y la estructura interna de los glaciares del Aneto y la Maladeta cartografiados por geo-radar de ultra-alta frecuencia (UHF). In La nieve en las cordilleras españolas. Madrid, Ministerio de Medio Ambiente, 227-249.

Martínez de Pisón, E. and M. Arenillas. 1988. Los glaciares actuales del Pirineo español. In La nieve en el Pirineo español. Madrid, Ministerio Obras Públicas y Urbanismo, 29-98.

Messerli, B. 1980. Mountain glaciers in the Mediterranean area and in Africa. International Association of Hydrological Sciences Publication 126 (Riederalp Workshop 1978 - World Glacier Inventory), 197-211.

Osmaston, H. 1975. Models for the estimation of firnlines of present and Pleistocene glaciers. In Peel, R., M. Chisholm and P. Haggett, eds. Processes in physical and human geography. Bristol, Heinemann, 218-245.

Pappalardo, M. 1999. Remarks upon the present-day condition of the glaciers in the Italian Maritime Alps. Geogr. Fís. Din. Quat., 22(1), 79-82.

Russell, H. 1908. Souvenirs d'un montagnard: 1858-1878. Pau, A. Liv. Pyr.

Schrader, F. 1894. Sur 1'étendue des glaciers des Pyrénées. Ann. Club Alpin Français 21, 403-423.

Serrat, D. 1980. Catálogo de los glaciares de la Península Ibérica. Notas de Geografía Física 2, 35-55.

MS received 22 May 2002 and accepted in revised form 25 June 2003 